S. Khmelevskiy, V. Sai, A. Samokish, O. Chekunova

Ivan Kozhedub Kharkiv Universiry of Air Force, Kharkiv

\title{
RECOMMENDATIONS DEVELOPMENT FOR THE SELECTION OF INFORMATION MODELS OF AIR CONDITIONING IN SPECIAL PURPOSE AUTOMATED CONTROL SYSTEMS
}

The article presents the results of the analysis of the method of developing recommendations for the selection of information models of the air situation in automated control systems for special purposes. Psychophysical features and processes of operative thinking of the operator of automated control systems are analyzed. It is substantiated that the task of developing recommendations for the selection or development of information models is a priority in the construction of any information model of air conditions. It is proved that the methods of encoding and decoding information used to process received signals prompt and efficient assimilation of information by the operator of automated control systems. Requirements for the characteristics of signals transmitted to the operator and methods of their coding, taking into account the characteristics of visual analyzers, memory, operational thinking. It is determined that the proposed method of analysis and selection of information models makes it possible to process all the characteristics of the signals transmitted to the operator, taking into account the characteristics of visual analyzers, memory and operational thinking. Practical researches on the basis of the developed software product which have confirmed efficiency of this method for a choice of information models are carried out. In order to increase the efficiency of decision-making by the operator of automated control systems, it is proposed to highlight not only current information, but also possible options for the operator's actions in this situation. According to the results of research, which are reflected in this article, it is stated that the use of this method is appropriate for testing information models of the reflection of the air situation when deciding on the effectiveness of their application.

Keywords: information element, informational model, human-machine system, operational thinking, automated control system, sign system.

\section{Introduction}

Formulation of the problem. In the conditions of modern air combat with its suddenness, ephemerality, determination of actions and high manufacturability of armament, the time spent on decision-making plays a crucial role.

High speed, maneuverability and modern equipment for suppression of radar detection means allow the enemy's air attack means to reach the object of attack quickly and imperceptibly, and high-precision and effective weapons to destroy this object. The number of factors that need to be taken into account when making a decision has also increased.

All this significantly reduces the time to decide that in air combat, can lead to an inability to effectively repel the enemy's attack. Therefore, the automation of the management of troops and armaments plays an important role in the conduct of hostilities. Thanks to the automated control systems (ACS), the operator does not need to consider and solve the full range of tasks, but to focus on solving the main issue. And the recommendations issued by the automated control systems can significantly improve the efficiency and quality of management, which in modern air combat is the key to victory [1-2].
The main way in which the operator receives information about the situation and the state of the managed object is the information model (IM). IM is an element of interaction between an operator and ACS. Thanks to IM, the operator forms the necessary images in operational thinking, through which the decisionmaking process of the operator. Therefore, it is obvious that the compliance of the information model with psychophysical features and the optimal conditions of the operator depends on both the time for decision-making and the effectiveness of this decision. It follows that the task of making recommendations on the choice or development of IM is a priority in the construction of any IM, but the ACS as a whole [3].

The analysis of recent researches and publications. From the analysis of open publications, to date, we can determine that the most important stage of the operator is to receive information about the state of the object of management during the management process. The main mental processes involved in the reception of information are such cognitive processes as sensation, perception, representation.

Sensation is the simplest mental process, which consists in the reflection of certain properties of objects and phenomena of the material world, as well as the internal states of the organism under the direct influence 
of stimuli on the sense organs. In other words, sensation is the transformation of the energy of external irritation into the fact of consciousness [4].

Based on the synthesis of sensations, a more complex form of reflection is formed - perception, which is a process of holistic reflection of objects and phenomena of the material world that act at this time on the human senses [5].

The next step is to distinguish the signal, resulting in the formation of a perceptual image, reveals a particular set of features of the signals.

The final stage of the perception process is the recognition (decoding) of the signal. After that, the information value carrying the received signal is obtained.

On the basis of sensation and perception there is a more complex form of sensory reflection - representation. Representation is a process of reflection of those objects and phenomena which at this moment do not act on sense organs [6].

Accordingly, recommendations for the choice of information models should be formed on the basis of the characteristics of these cognitive processes and basic human analyzers.

The aim of the article - is to develop recommendations for the choice of information model of the air situation in automated control systems for special purposes, each item of which is based on an analysis of the operator.

\section{Statement of basic materials}

To develop an effective method of choosing an information model, you need to consider the main factors that affect the operator when making a decision. The main factors that determine the time to make a decision are:

- features of the visual analyzer of the ACS operator;

- features of operational thinking that are inherent in the operator;

- images that the operator implements in his mind during decision-making.

\section{Characteristics of visual analyzer}

From the principles of the human eye, we can draw two main conclusions that determine the visibility of signals:

- visual sensation of any object depends on brightness;

- the difference of objects against the background of other objects is determined by its contrast with the background [7].

There are two types of contrast: direct (subject darker than the background) and inverse (subject brighter than the background).

$$
\begin{aligned}
& K_{\text {dir }}=\frac{A_{0}-A_{1}}{A_{0}} ; \\
& K_{\text {inv }}=\frac{A_{1}-A_{0}}{A_{1}},
\end{aligned}
$$

where, $A_{0}$ and $A_{1}-$ the brightness of the background and the subject.

The optimal contrast value is considered to be 0.6 0.9 .

The dependence of the threshold contrast on the brightness and angular dimensions of the sign are shown in Fig. 1.

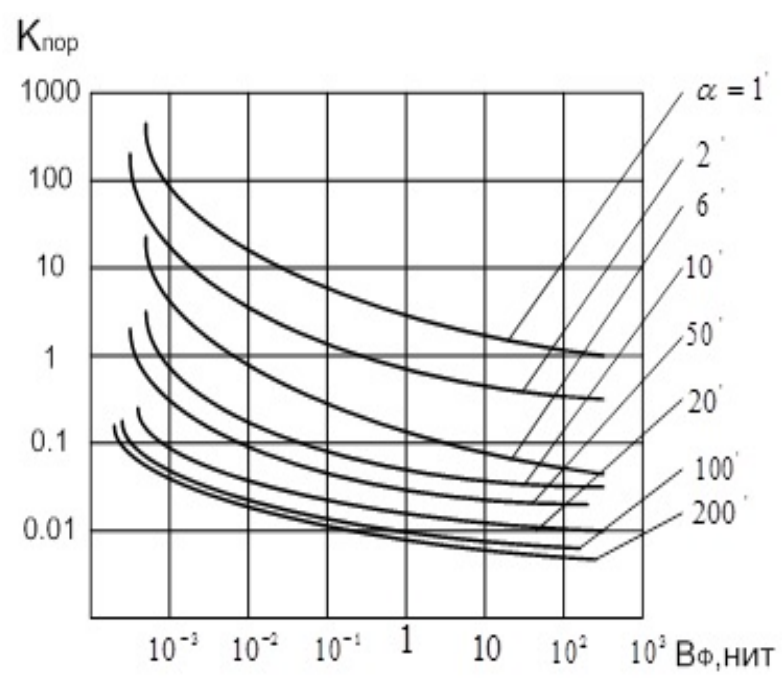

Fig. 1. The dependence of the threshold contrast on the brightness and angular dimensions of the sign Source: author's development.

\section{Features of operational thinking}

The activity of the operator is characterized by a special type of thinking - operational thinking.

Operational thinking is a way of solving practical problems, which is carried out on the basis of modeling by the operator of objects of labor activity, resulting in a situation of modeling the expected set of actions (plan of operations), which ensures the achievement of the goal [8]. Thus, operational thinking includes the task of identifying a problem situation and a set of its imaginary practical transformations.

Operational thinking usually takes place in strictly limited time norms. In other words, an important feature of operational thinking is the presence of extreme conditions [9].

The next distinguishing feature of operational thinking is the large share of decoding operations. After all, it receives all the necessary information using an information model, is in coded form [10]. 


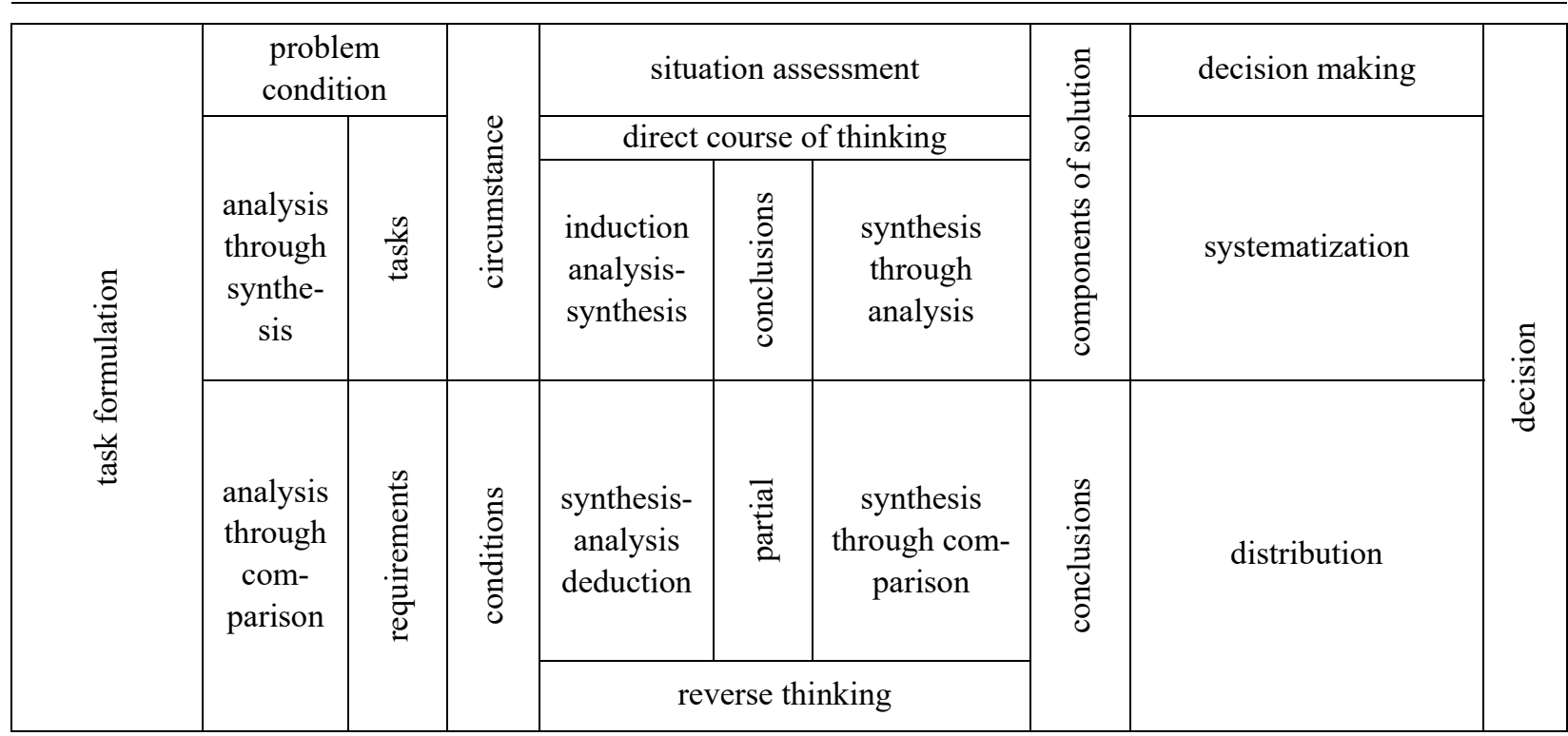

Fig. 2. The structure of operational thinking Source: author's development.

In the mental process of assessing the situation, there is certainly a transition from partial to more general conclusions. The movement of the operator's thought goes from facts to conclusions and develops according to the scheme "analysis - synthesis". Their correctness is checked by comparison with the facts, ie by deductive operations. Thus, the reverse course of thought in the verification of partial conclusions follows the scheme "synthesis - analysis" [11].

At the last stage of the mental act - registration of the decision the operator needs to place the received conclusions in a certain sequence by their corresponding classification and distribution on decision points [12].

\section{The role of images in the activities of the operator}

The operational image is formed as a result of comparing the current information about the state of the object with the information about it that was previously accumulated by the operator. The operational image is some available information about the object (image information), reflected in the mind and actively interacting with the signal information [13].

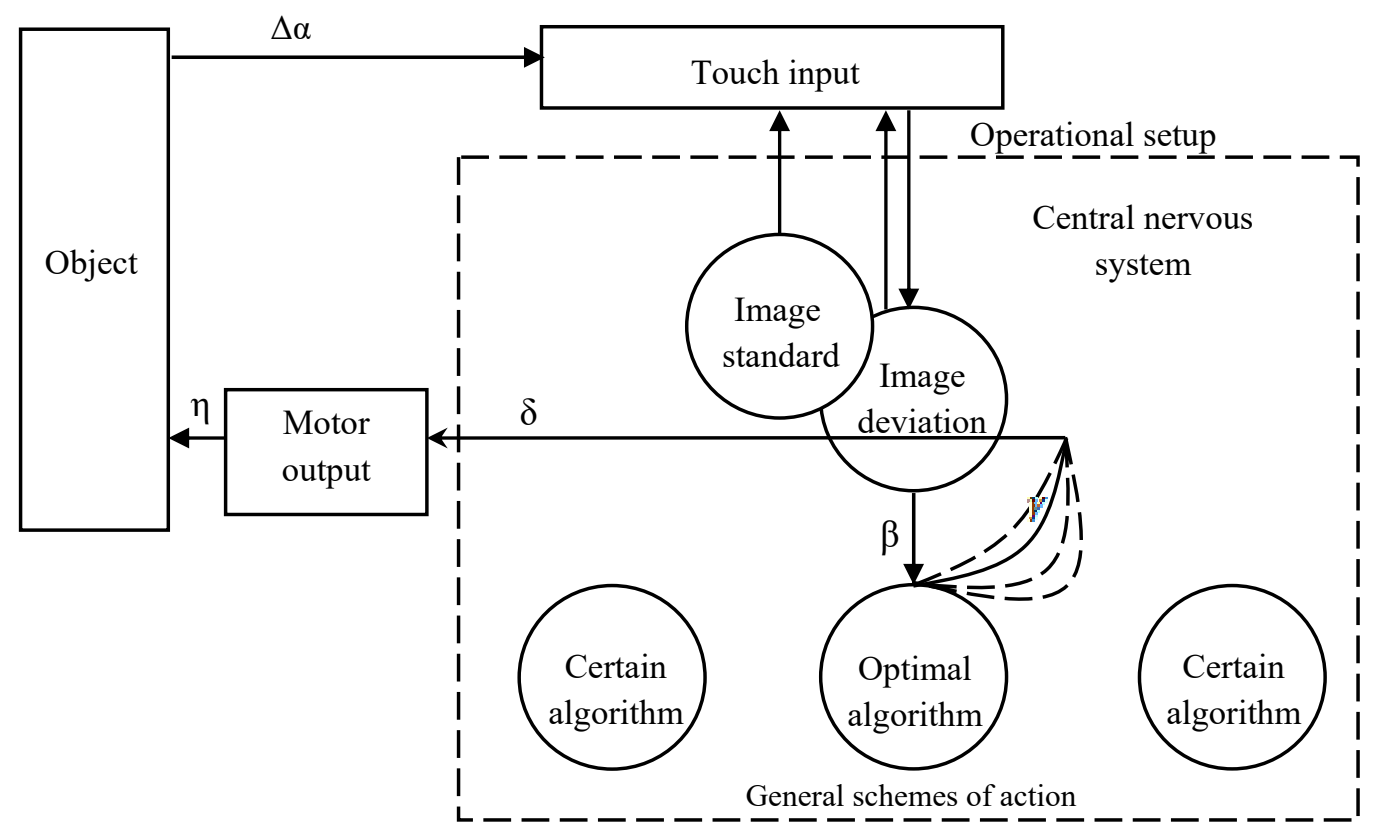

Fig. 3. The scheme of the operator subject activity

Source: author's development. 
After analyzing all these elements, it is possible to obtain an information element that is suitable for use in IM reflection of the air situation. Based on this, a block diagram of the algorithm for developing an information element was built. The algorithm for developing an information element includes an analysis of the results obtained during the study. For this problem from the obtained results it is necessary to determine and analyze: mathematical expectation of information processing time by the operator, estimation of probability of the correct answer and probability of an error. To determine them, the formulas of mathematical expectation and statistical probability were used [14].
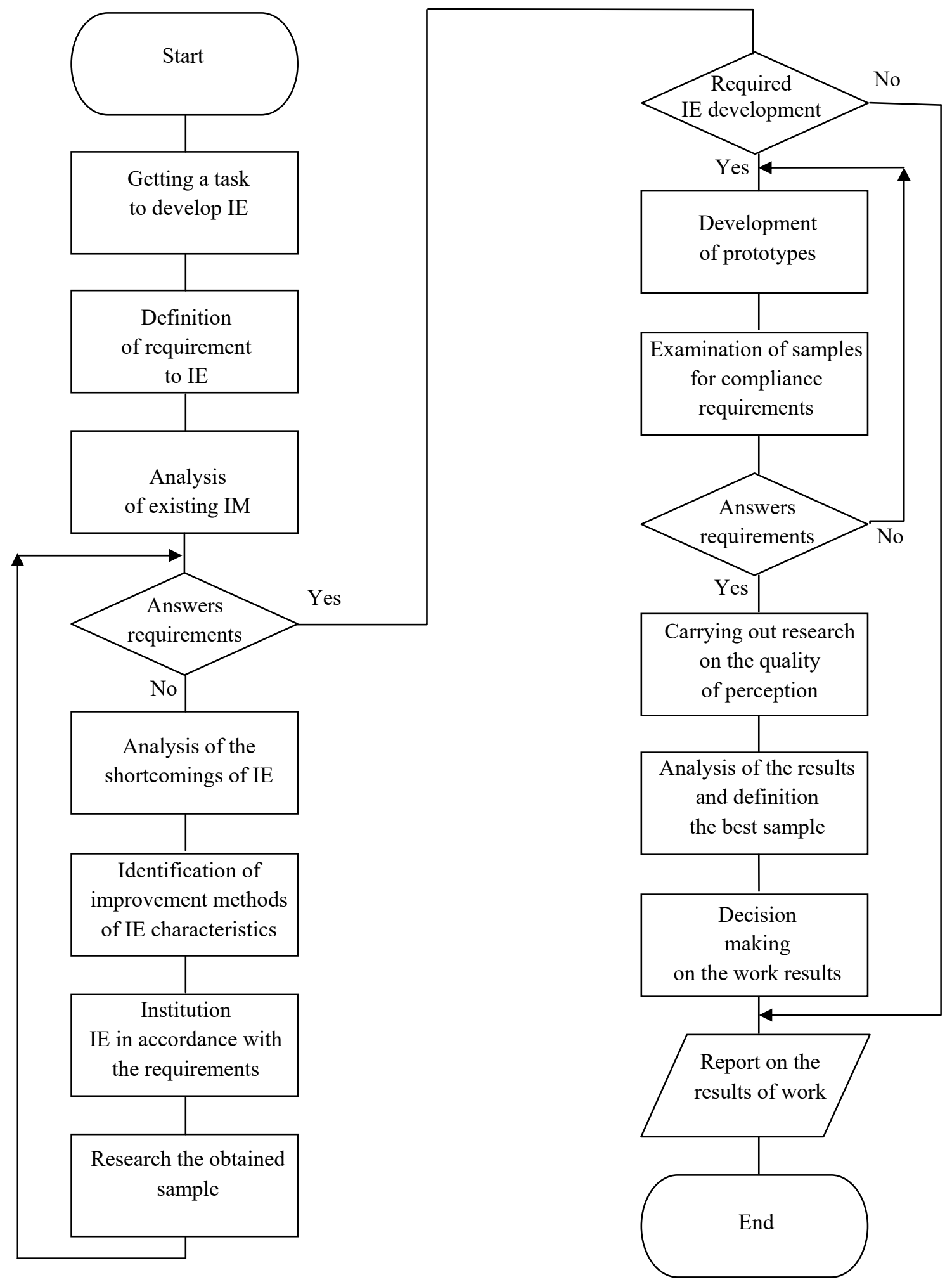

Fig. 4. Development of recommendations for the selection of information models of the air situation Source: author's development. 
Having determined these parameters, we form a conclusion about the processing speed of the element by the operator and the accuracy of its recognition, but to compare samples and determine the best it is necessary to have a generalized estimate of each sample which would include the values of all necessary parameters. The essence of the method is that the system-wide indicator is calculated, and the preferred prototype is the one in which this indicator is maximum.

\section{Conclusions}

To solve the problem of increasing the efficiency of decision-making by the ACS operator, it is necessary to take into account the main psychophysical factors that affect this process. Such factors include:

- features of the visual analyzer of the ACS operator, and factors that may affect its sensitivity;
- features of operational thinking, which is a necessary element of the decision-making system in a limited period of time;

- images that are formed in the mind of the operator in order to process information using algorithmic actions.

With the help of the proposed method of information model selection it is possible to analyze the requirements for signals, to develop and study information elements and information models of air situation display.

Practical studies have shown the feasibility of the proposed method for selecting an information model by determining quantitative parameters such as decision time, the probability of correctness and error of the decision that affect the activities of the ACS operator.

\section{References}

1. Pavlenko M., Polishchuk S., Khmelevsky S., Kuboko S. A method for developing a system of information support for the processes of assessing the state of control objects. Science and Technology of the Air Force Ukraine. 2014. № 1(14). P. 161166.

2. Gryb D., Demidov B., Khmelevsky S., Matyushchenko O. Intellectual technologies in problems of management of structural dynamics of complex multistructural systems of military purpose. Information processing systems. 2019. № 3(158). P. 15-26. https://doi.org/10.30748/soi.2019.158.02.

3. Borozenets I. O. Information support of decision-makers in automated air traffic control systems. Kharkiv : KNAFU, 2020. $242 \mathrm{p}$

4. Mathematical model of the psychological standard of the ACS operator by air movement / Shcherbak G. V. et all. Problems of informatization: abstracts of the report: VII International Scientific and Technical Conference, Kharkiv, 2019. 34 p.

5. Shylo S. G., Borozenets I. O., Dmitriiev O. M. Activities of the operator of the automated air traffic control system. Modern directions of development of information and communication technologies and means of management : abstracts of the report. VIII International Scientific and Technical Conference. Baku, Kharkiv, 2019. 33 p.

6. Shylo S. G., Borozenets I. O., Dmitriiev O. M. Research of the model of functional activity of the operator of the automated air traffic control system. The use of information technology in the training and operation of law enforcement forces : Collection of Abstracts of Reports of the International Scientific-Practical Conference. Kharkiv, 2019. 32 p.

7. Borozenets I. O., Shylo S. G., Dmitriiev O. M. Model of psychological portrait of the operator of the automated air traffic control system. Topical Issues of Ensuring the Service and Combat Activities of Military Formations and Law Enforcement Agencies : abstracts of the report. VIII International scientific and technical conference, Kharkiv, 2019. 29 p.

8. Shylo S. G., Borozenets I. O., Dmitriiev O. M. Development of a model of functional activity of the operator of the automated air traffic control system. Topical issues of ensuring the service and combat activities of military formations and law enforcement agencies : abstracts of the report. VIII International Scientific and Technical Conference, Kharkiv, 2019. $47 \mathrm{p}$.

9. Methods of building a model of psychological portrait of the automated air traffic control system / Shcherbak G. V. et all. Weapons systems and military equipment. 2019. № 3(61). P. 53-62

10. Fundamentals of technical operation of information and telecommunication systems of AMS by aviation and air defense of the Armed Forces of Ukraine / Borozenets I. O. et all. Kharkiv : KNAFU, 2020. 268 p.

11. Ivanov S. G., Onipchenko P. M., Ryapolov E. I. Tactics of the Air Force: a synopsis of lectures for students, cadets and students of higher educational institutions. Kharkiv : KNAFU, 2014. 332 p.

12. Automated and information systems of Air Force control points / Barannik V. V. et all. Kharkiv : KNAFU, 2020. 132 p.

13. Method of psychodiagnostic tools' determination for professional selection and training of specialists in complex ergatic systems. Dmitriiev O. et all. Kharkiv : KNAFU, 2019. 93 p.

14. Automated control system "Oreanda-PS". Kyiv : Aerotechika, 2019. URL: http://surl.li/axrlg (accessed 01.11.2021).

15. Digital measurement of the Armed Forces. Under what conditions it is possible. Defense industrial courier : web site. URL: http://opk.com.ua/digital-measurement-of-the-Armed-Forces (accessed 01.11.2021).

Received by Editorial Board 01.11.2021

Signed for Printing 14.12.2021

\section{Відомості про авторів:}

\section{Хмелевський Сергій Іванович}

кандидат технічних наук старший науковий співробітник начальник кафедри Харківського національного університетуПовітряних Сил ім. І. Кожедуба, Харків, Україна

https://orcid.org/0000-0001-6216-3006

\section{Information about the authors:}

\section{Serhii Khmelevskiy}

$\mathrm{PhD}$ in Engineering Senior Researcher

Head of Department of Ivan Kozhedub Kharkiv National

Air Force University,

Kharkiv, Ukraine

https://orcid.org/0000-0001-6216-3006 
Сай Владислав Валерійович

курсант

Харківського національного університету

Повітряних Сил ім. І. Кожедуба,

Харків, Україна

https://orcid.org/0000-0001-6773-7726

\section{Самокіш Артем Валерійович} викладач

Харківського національного університету

Повітряних Сил ім. І. Кожедуба,

Харків, Україна

https://orcid.org/0000-0003-1924-9351

Чекунова Оксана Миколаївна кандидат технічних наук провідний науковий співробітник

Харківського національного університету

Повітряних Сил ім. І. Кожедуба,

Харків, Україна

https://orcid.org/0000-0001-9613-7244

\section{Vladyslav Sai}

Cadet

of Ivan Kozhedub Kharkiv National

Air Force University,

Kharkiv, Ukraine

https://orcid.org/0000-0001-6773-7726

\section{Artem Samokish}

Lecturer

of Ivan Kozhedub Kharkiv National

Air Force University,

Kharkiv, Ukraine

https://orcid.org/0000-0003-1924-9351

\author{
Oksana Chekunova \\ $\mathrm{PhD}$ in Engineering \\ Leading Researcher \\ of Ivan Kozhedub Kharkiv National \\ Air Force University, \\ Kharkiv, Ukraine \\ https://orcid.org/0000-0002-9613-7244
}

\title{
РОЗРОБКА РЕКОМЕНДАЦІЙ ПО ВИБОРУ ІНФОРМАЦІЙНИХ МОДЕЛЕЙ ПОВІТРЯНОЇ ОБСТАНОВКИ В АСУ СПЕЦІАЛЬНОГО ПРИЗНАЧЕННЯ
}

\author{
С.І. Хмелевський, В.В. Сай, А.В. Самокіш, О.М. Чекунова
}

У статті представлені результати аналізу методу розробки рекомендацій по вибору інформаційних моделей повітряної обстановки в автоматизованих системах управління спеціального призначення. Проаналізовано психофізичні особливості та процеси оперативного мислення оператора автоматизованих систем управління. Обтрунтовано, шьо задача розробки рекомендацій, щодо вибору або розробки інформачійних моделей є першочерговим завданням при побудові будь-якої інформачійної моделі відображення повітряної обстановки. Доведено, що методи кодування $і$ декодування інформаиії, щзо застосовуються для обробки прийнятих сигналів, мають відповідати вимогам, щуо сприяють оперативному і ефективному засвоюванню інформації оператором автоматизованих систем управління. Висунуті вимоги до характеристик сигналів, що передаються оператору, та методів їх кодування з урахуванням особливостей зорових аналізаторів, пам'яті, оперативного мислення. Визначено, щз запропонований метод аналізу та вибору інформачійних моделей дає можливість опрацювання всіх характеристик сигналів, щуо передаються оператору, з урахуванням особливостей зорових аналізаторів, пам'яті та оперативного мислення. Проведені практичні дослідження на основі розробленого програмного продукту, які підтвердили прачездатність даного методу для вибору інформачійних моделей. Задля підвищення ефективності ухвалення рішення оператором автоматизованих систем управління пропонується на засобах відображення висвітлювати не тільки поточну інформацію, але й можливі варіанти дій оператора в цій ситуації. За результатами досліджень, які відображені в даній статті стверджується, що використання даного методу є доцільним для тестування інформачійних моделей відображення повітряної обстановки під час ухвалення рішення щзоо ефективності їх застосування.

Ключові слова: інформаційний елемент, інформаційна модель, людина-машина, операчійне мислення, автоматизована система управління, знакова система.

\section{РАЗРАБОТКА РЕКОМЕНДАЦИЙ ПО ВЫБОРУ ИНФОРМАЦИОННЫХ МОДЕЛЕЙ ВОЗДУШНОЙ ОБСТАНОВКИ В АСУ СПЕЦИАЛЬНОГО НАЗНАЧЕНИЯ}

\section{С.И. Хмелевський, В.В. Сай, А.В. Самокиш, О.Н. Чекунова}

В статье представлены результаты анализа метода разработки рекомендаций по выбору информационных моделей воздушной обстановки в автоматизированных системах управления специального назначения. Проанализированы психофизические особенности и процессы оперативного мышления оператора автоматизированных систем управления. Обосновано, что задача разработки рекомендачий по выбору или разработке информачионных моделей является первоочередной задачей при построении любой информачионной модели отражения воздушной обстановки. Доказано, что методы кодирования и декодирования информации, применяемые для обработки принимаемых сигналов, должны отвечать требованиям, способствуюшим оперативному и эффективному усвоению информации оператором автоматизированных систем управления. Выдвинуты требования к характеристикам сигналов, передаваемых оператору, и методам их кодирования с учетом особенностей зрительных анализаторов, памяти, оперативного мышления. Определено, что предложенный метод анализа и выбора информационных моделей дает возможность проработки всех характеристик передаваемых оператору сигналов с учетом особенностей зрительных анализаторов, памяти и оперативного мышления. Проведены практические исследования на основе разработанного программного продукта, подтвердившие работоспособность данного метода для выбора информационных моделей. Для повышения эффективности принятия решения оператором автоматизированных систем управления предлагается на средствах отображения освещать не только текущую информацию, но и возможные варианты действий оператора в данной ситуации. По результатам исследований, которые отражены в данной статье, утверждается, что использование данного метода иелесообразно для тестирования информационных моделей отражения воздушной обстановки при принятии решения об эффективности их применения.

Ключевые слова: информационный элемент, информационная модель, человек-машина, операционное мышление, автоматизированная система управления, знаковая система. 